( T. Hoffmann, professor, Lodz University, Poland

\title{
A TRANSFER OF MODERN TECHNOLOGIES FROM UNIVERSITIES TO SMES-ORGANISATIONAL - THE PICTURE IN POLISH MEDIA
}

The author of this article focuses mostly on new challenges that await particular scientific centers which create a value added as scientific researches and help out with their commercialisation. The result of this kind of outlined cooperation is creating a new quality in scientific researches area which propounds itself in a specific, practical application in different enterprises. The article presents the technology transfer in a structural approach and focuses on an institutional system that was thoroughly researched and examined from a utility and efficiency points of view. The hypothesis that was stated in principles of the article in question shows itself in an ascer-

tainment that the transfer of technology is undoubtedly needed in universities, however for now there are no friendly law or organisational conditionings. What is more, there is a constant rivalry and mutual reluctance between universities and entrepreneurs.

A new law has been resolved and its establishments came into existence in October 2011. A new act (in its authors' opinion) is supposed to enlarge the autonomy of academies, improve the quality of education and also hasten academic career of employees 1 .

Keywords: transfer; technology; SMEs-organisation; Polish media; university; business-company; law; Civic Platform.

\section{Introduction}

Higher education in Poland started to rapidly develop after constitutional, political and economic changes that have been presented in 1989. It is estimated that in years from 1992 to 2009, almost 326 non-public academies came into being- together with public universities the today's number increased to 458 academies$^{2}$. At first, universities functioned according to the higher education act of 19903 . Alternatively, there were also used acts' regulations from the 31.03 .1965

1. http://www.nauka.gov.pl/ministerstwo/aktualnosci/aktualnosci/artykul/noweprawo-o-szkolnictwie-wyzszym-podpisane-przez-prezydenta/. Entered on: 01.03.2012.

2. http://www.nauka.gov.pl/szkolnictwo-wyzsze/dane-statystyczne-o-szkolnictwiewyzszym/. Entered on: 1.05.2018.

3. The Act of 12.09.1990 on Higher Education, Dz. U. (Polish Journal of Laws) from 1990 , No. 65 , pos. 385 .

(C) $2018 \mathrm{p}$. 
on higher military education 4 and from the 26.06.1997 on higher vocational schools 5 .

Because of running out of a firstly accepted legal formula, in 2005 the higher education law has been legislated 6 . It regulated some so far controversial aspects in a complex way?

Statute in question regulated the rules of functioning of public and non-public academies. What is more, it also specified the status of academies' employees, agencies and a constitutional system that was accepted in a certain unit. In spite of its maladjustment to further trends resulting from globalisation and internationalisation processes, the PO-PSL coalition government (PO - Civic Platform, PSL - Polish Peasants' Party) that came into being in 2007 decided to implement completely innovational (as for Polish legal basis) solutions for academies and their role in economy based on knowledge.

A new law has been resolved and its establishments came into existence in October 2011. A new act (in its authors' opinion) is supposed to enlarge the autonomy of academies, improve the quality of education and also hasten academic career of employees ${ }^{8}$.
It emphasizes the fact that a general role of universities is upbringing and education of students as well as conducting scientific researches by the employees. Didactic and research processes happening in academies of higher education cause situations when interactions with intellectual and industrial property laws become inevitable. That is where one can see arising interactions between universities and a transfer of technology to enterprises. The fundamental research aim of this article is to present the essence of the transfer of modern technology from universities to enterprises.

The author of this article focuses mostly on new challenges that await particular scientific centers which create a value added as scientific researches and help out with their commercialisation. The result of this kind of outlined cooperation is creating a new quality in scientific researches area which propounds itself in a specific, practical application in different enterprises. The article presents the technology transfer in a structural approach and focuses on an institutional system that was thoroughly researched and examined from a utility and efficiency points of view. The hypothesis that was

4. The Act of 31.03.1965 on Higher Military Education, Dz. U. (Polish Journal of Laws) from 1992, No. 10 , pos. 40 , with later change.

5. The Act of 26.06.1997 on Higher Vocational Schools, Dz. U. (Polish Journal of Laws) No. 96 , pos. 590 , with later change.

6. The Act of 27.07.2005, Higher Education Law, Dz. U. (Polish Journal of Laws) from 2005, No 164, pos. 1365.

7. They were particularly about enlargement and dissemination of access to education on the higher school level. Moreover, some pathological solutions were supposed to be liquidated, because of their tendency to a multi-jobbing of employees and also of a quite law level of education. The law was partly an answer to changes made by Bologna Process.

8. http://www.nauka.gov.pl/ministerstwo/aktualnosci/aktualnosci/artykul/noweprawo-o-szkolnictwie-wyzszym-podpisane-przez-prezydenta/. Entered on: 01.03.2012. 
stated in principles of the article in question shows itself in an ascertainment that the transfer of technology is undoubtedly needed in universities, however for now there are no friendly law or organisational conditionings. What is more, there is a constant rivalry and mutual reluctance between universities and entrepreneurs.

\section{The essence and genesis of the technology transfer}

The technology transfer is a phenomenon that very often accompanies innovational process$\mathrm{es}^{9}$. A technical information flow is its essence10. Furthermore, other authors claim that the technology transfer focuses not only on a flow of information, but technology and information 11 . Therefore, information and knowledge have a great meaning in this area of interest. Firstly, an information about a new technology disseminates and then a technology knowledge flows 12 . D. Sachal assumes that if a technical product is being transferred, it is accompanied by a transfer of knowledge that it is based on 13 . What is more, another authors claim that the technology transfer is based on an exchange of knowledge about existence and rules of machines and devices functioning and on an exchange of machines and devices themselves ${ }^{14}$. Moreover, J. Małecki assumes that the technology transfer contains all of the forms of innovation and technical education diffusion. It is very often a market process in which technology is being bought and sold15. As it can be observed, in the doctrine there is a variety of formulations on the technology transfer. Generally, it can be assumed that the technology transfer represents a transmission of technological knowledge from scientific centers (including universities) to economy, so to enterprises. The technology transfer can have a vertical and a horizontal form [see of illustration].

It seems that aims of the vertical and horizontal technology transfer differ from each other. The aim of a flow of a new technological knowledge from research institutions to industry is usually a technical innovation, whereas the aim of flows between companies is basically a diffusion of innovation. Therefore, making inventions accessible by research institutions or universities to enterprises is treated as a sign of the vertical transfer, while diffusion as the ho-

9. It usually is a principle of a technological innovation.

10. T. Allen, Managing the Flow of Technology, Cambridge 1984 [after:] Z. Chyba, W. M. Grudzewski, Przedsiębiorczość akademicka w Polsce. Osiąganie przewagi konkurencyjnej w wyniku komercjalizacji technologii, Warsaw 2011, page 61.

11. S. Radosevic, International Technology Transfer and Catch-up in Economic Development, London 1999, pages 12-13.

12. Z. Chyba, W. M. Grudzewski, Przedsiębiorczość akademicka w Polsce. Osiąganie przewagi konkurencyjnej w wyniku komercjalizacji technologii, Warsaw 2011, page 61.

13. D. Sahal, Chance and Opportunity in Technological Innovation, Oxford 1982, page 21.

14. Compare: A. H. Jasiński, Innowacje i transfer techniki w procesie transformacji, Warsaw 2006, page 21.

15. J. Małecki, Transfer technologii, Warsaw 2012, pages 14-15. 


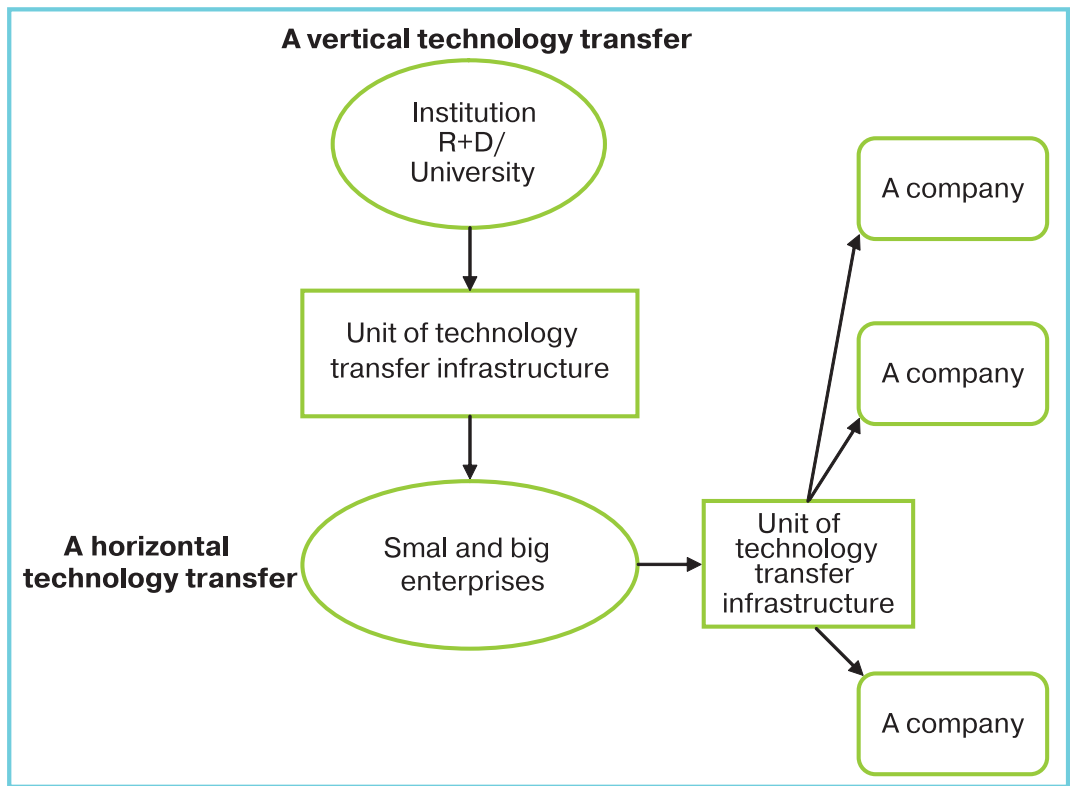

A vertical and horizontal technology transfer

Source: Z. Chyba, W. M. Grudzewski, Przedsiębiorczość akademicka w Polsce. Osiąganie przewagi konkurencyjnej w wyniku komercjalizacji technologii, Warsaw 2011, page 64.

rizontal transfer 16 . The technology transfer was even present in ancient China that was way ahead of certain continents in terms of technological novelty 17 . In time, modern technologies spread to Europe and other continents. England was one of the countries that particularly benefited from changes happening thanks to technology the English gained many modern technological solutions ${ }^{18}$.

Nowadays, the technology transfer in highly developed coun- tries is particularly expanded and it is characterised with a quite wide variety of organisational forms. In most of the European countries and in United States, within a technology transfer system there are included universities, extramural research units, chambers of commerce and industry, economic associations, etc. However among them, science and technology parks have a special meaning. Another form of the technology transfer are enterprises created

16. Z. Chyba, W. M. Grudzewski, Przedsiębiorczość akademicka w Polsce. Osiaganie przewagi konkurencyjnej w wyniku komercjalizacji technologii, Warsaw 2011, page 64.

17. For example, the Chinese were first to invent porcelain in a first half of the seventh century. What is more they also invented water turbine and fans used to propelling piston pumps.

18. More: W. M. Grudzewski, I. K. Hejduk, Projektowanie systemów zarządzania, Warsaw 2001, page 373 and next. 
by scientists or universities and enterprises that represent innovational branches of the economy ${ }^{19}$.

The technology transfer is widespread in countries of Western Europe and also greatly in the United States. In Poland, people have only just started to learn how to lead a process of technology transfer in a correct way and what is the best method of commercialising scientific research results. In that country, the technology transfer creates some kind of reluctance, especially among older people that might not entirely understand the idea of it, the rules of functioning and potential benefits that it can bring to the country.

\section{The technology transfer in Poland}

In Polish conditions, to make processes of the technology transfer more enhanced there are created various places such as: science and technology parks, enterprise and innovation incubators and also technology transfer and innovation centers 20 .

An essence of technological parks comes from the United States. It was the place where in 1948 the Bohanson Research Park has been created. There was also quite a rapid increase of development of this kind of organisations in Europe, especially in Germany where many similar institutions came into existence. A technological park is an initiated and financed by public resources economic complex that assists realisation of support of young and innovational enterprises' politics as well as optimisation of conditions of technology transfer and research results' commercialisation from scientific institutions to economic practice. Nowadays, there are 25 technological parks placed in Poland21.

Enterprise incubators can be defined as separated, organising and based on immovable enterprise centers which support a development of small companies (including those recently founded) through offering a local, trainings and advice services. In that case, an incubation process is based on preincubation, so training of a young entrepreneur, elaboration of a business model, incubation including planned projects, a preparation for investing and searching for financing sources and growth of a company through a development of a team, access to assets and entry to international markets. A typical academic incubator focuses mostly on a detailed process of incubation22. According to

19. More: K. B. Matusiak, Parki technologiczne. Instytucjonalne wspieranie przedsiębiorczości, procesów innowacyjnych i rozwoju regionalnego, Łódź 1995, page 125; M. Marchesnay, Technology and Competitiveness, Small an Medium-sized Enterprises, Paris 1993; J. Guliński, K. Zasiadły, Innowacyjna przedsiębiorczość naukowa - światowe doświadczenia, Warsaw 2005, pages 119-140.

20. Compare: Przewodnik. Komercjalizacja B+R dla praktyków, Warsaw 2010.

21. Including the oldest one - the Science and Technology Park in Poznań created in 1995 that runs with Foundation of Adam Mickiewicz's University.

22. There are some generally known enterprise incubators such as: Innovation and Enterprise Center of Greater Poland in Poznań near the University of Technology, Technological Center next to the University of Technology in Gdańsk, Progress and Business Incubator in Krakow and Enterprise Center near the University of Technology in Warsaw. 
the recent data, there are about 53 enterprise incubators functioning in Poland, in which there are 1200 working subjects making 4800 job vacancies 23 .

Centers of Technology Transfer and Innovation are included in academic structures dealing with the technology transfer. Principal aims of activities of centers in question are: valorisation of scientific and innovational potential in a region, elaboration of pre-investment studies, identification of innovational needs and popularisation, promotion and development of technological enterprise 24 . Universities of Technology have the greatest potential in creating Centers of Technology Transfer and Innovation.

Scientists hired in that kind of university, by using its properties, become authors of more than tolerable innovational technologies that spread in the country and even in the world. Hence some of the universities' decisions to create Centers of Innovation and Technology Transfer Development. Their aim is a transfer and commercialisation of scientific research results and preventing earlier described situations.

They are created with a purpose of a practical use of universities' intellectual potential in a country's economy. The closely cooperate with a variety of institutions in a process of transfer and thanks to that they have a regular access to technologies that are offered and looked for. They have knowledge about an intellectual property security and sources of innovation financing. Also, they often have an appropriate potential in obtaining union's funds and thanks to them they can accomplish some expensive aims. What is more, they make specific contact platform for scientists, students and entrepreneurs, they mediate in searching for recipients for elaborated by universities patents and technologies. Precious parts of activities are trainings conducted for employees and students of universities that are related to commercialisation of scientific elaborations. Moreover, they give advice and provide assistance in an inventions' patenting process, they also issue opinions on innovation of created technologies.

A case of functioning of these centers seems to be particularly important. A Polish scientists' knowledge level and a number of scientific publications coming into existence in national universities is very high. Besides that, a successful technology transfer to economy and drawing profits resulting from this process will give benefits to all interested sides. However, it requires continuation and consistency in already started work on building the consciousness and changing a way of thinking about economic values, potential and studies' effects.

Organisationally, Centers of Innovation and Technology Transfer Development are very often staff divisions of a rector or a chancellor

23. Z. Chyba, W. M. Grudzewski, Przedsiębiorczość akademicka w Polsce. Osiaganie przewagi konkurencyjnej w wyniku komercjalizacji technologii, Warsaw 2011, page 82.

24. Ibidem, page 86 . 
and they usually hire 1 to 5 employees 25 ; depending on needs, there can be also hired people for external projects only. In some Centers, their work focuses mostly on realisation of projects cofinanced with European Union resources or National Center of Research and Development, hence hiring some people for projects' needs. In spite of that, the main aim of activities of these university units is organisation of a wide contacts' area between researches and industry. Some of the centers focus on promoting university contacts and giving them legal forms 26 , other ones specialise in contacts with small and medium enterprises and help them to gain new technologies and professional knowledge.

Transfer's divisions are essential elements of universities' politics, making it possible to be more open to contacts with an economic practice and ipso facto to participate in regional activities stimulating an economic development. Through this kind of units, universities participate in creating new local incubators of modern technologies and technological parks 27 . Centers of Innovation and Technology Transfer Development can be created in a form of university units as well as commercial law partnerships. A legislator in a new regulation related to higher education decided to give a possibility to create this type of organisations. What is more, in a present reality it seems that without this kind of institutions universities are doomed, especially if it is a university with a technological profile. However, Centers of Technology Transfer that conduct researches in a social sciences area can also be met in universities. In this case, Centers join studying and business together and they try to implement some already worked out solutions to small and medium enterprises to increase their competitive predominance 28 .

The legislator assumes that in purpose to commercialise scientific researches' results and a developmental work universities can create a limited liability company or a joint-stock company 29 . Tasks of this company would include embracing shares in other limited companies or creating new companies that are appointed to implement the scientific researches' results or the developmental work, likewise to administer the

\section{The Center of Transfer and Innovation of Poznań's Technology University hires 16} people.

26. It is based on drawing up agreements, contracts and other settlements that aim to create innovational values.

27. A. Bąkowski, P. Głodek, M. Gołębiowski, K. Gulda, A. Jewtuchowicz, M. Klepka, K. Lityński, K. B. Matusiak, M. Matusiak, M. Mażewska, P. Niedzielski, A. Nowakowska, E. Stawasz, K. Zasiadły, (red), Innowacje i transfer technologii. Słownik Pojęć, Warsaw 2005, pages 21-24.

28. Ibidem, page 12.

29. A procedure of creating this kind of company is based on appointing it by a rector, with a senate's or another collegial body's permission. It can also be a different type of companies: general partnership, limited liability partnership, limited partnership business entity or partnership limited by shares. 
industrial property laws in a form of commercialisation 30 . Universities can also join different companies, cooperatives or economic organisations 31 . In this context, an important question reveals: can a university that creates a commercial law partnership in a form of the Center of Technology Transfer and with its help it effectuates the technology transfer and commercialisation of scientific researches operate a business? It seems that with present law regulations universities can operate a business exceeding an economic activity that is described in art. 106 of Higher Education Law.

It is also assumed that art. 7 of the law in question does not include limits on a range in which universities can operate the business. In this context, it is wise to imply that rules of operating a separated economic activity are regulations that will be used in narrowly defined economic operations of a university. The legislator transfers decisions on the issue to hands of statutes and universities' senates regulations 32 .

Hence it can be established that the Senate of a public university can appoint a commercial law partnership based on appropriate decisions of a statute. The incorporated court will be in charge of controlling a partnership creation. What is more, if operating the activity involves a disposal of permanent assets' elements above their specified worth, to make the action come into existence will require a permission of the Ministry of State Treasury33. Therefore, for the purpose of the technology transfer universities can create companies and other partnerships that will aim to accomplish their statutory activities and also operate businesses. It is worth to consider an access to laboratories for small and medium enterprises or a permission to conduct (paid) scientific researches on their behalf. Finally - an initiation of their own researches and their commercialisation.

\section{Summary}

A matter of scientific researches results' commercialisation and technology transfer is an issue not fully explored yet in a Polish literature and practice, hence it seems that any actions undertaken by particular universities in this field will be based on experiences gained in a process of implementing new ideas. Undoubtedly, these experiences will be also gained in the way of appointing special purpose entities which will have a basic task of the commercialisation and technology transfer.

How will the public and nonpublic universities controlling this kind of units behave? Including

30. Art. 86a of the Act of 27.07.2005, Higher Education Law, Dz. U. (Polish Journal of Laws) from 2005, No. 164, pos. 1365. See also: Przewodnik. Komercjalizacja B+R, dla praktyków, Warsaw 2010, page 33.

31. Art. 62 of the Act 1 pnt. 8 of Higher Education Law.

32. Przewodnik. Komercjalizacja B+R, dla praktyków, Warsaw 2010, pages 33-34.

33. It was defined in the Act of 8.08.1996 on procedures for the exercise of implementing powers conferred on the Treasury, Dz. U. (Polish Journal of Laws) no. 106, pos. 493. 
the ones operating economic activities? Will scientific researchers use the proposed solutions? Finally, to what extend will the legislator's concept be realised? It is difficult to unequivocally define it for now. It seems that the issue of commercialisation and transferring modern technologies to small and medium enterprises is an exceptional chance for universities to develop their scientific activities and also gain some financial benefits for innovational ideas coming into being in universities and being implemented in enterprises. What is more, a rigorous cooperation of a science and business sector can get them closer to worldwide standards in this field.

In this article, the author presented institutions of the technology transfer in a dynamic approach. It seems, that an ability and a quality of building partnerships, network structures and searching of a consensus are crucial elements of an evaluation and legitimacy and also partly an efficiency of institutions taking part in the technology transfer.
Therefore, a thesis that universities look for their activity fields all the time while building ever so new partnership institutions such as Academic Enterprise Incubators and Centers of Innovation and Technology Transfer Development can be stated. However, a number of these institutions is not identified with a quality. Mostly, they are directed on union's financing and brought under logics of adjusting to application requirements.

L. Kwieciński assumed that these institutions and their provenance are related to region's needs in an insufficient degree ${ }^{34}$. There is a serious lack of specialists, qualified personnel and a permanence effect, so surviving without national or European donations. That is why these institutions require a permanent monitoring and verification of their actions. Even in spite of some negative assertions, these institutions are very much needed and also essential to develop a widely understood innovational politics that functions in European, partly national and very slowly in regional perspective.

\section{References}

1. Allen, T. (2011). Managing the Flow of Technology, Cambridge 1984 [after:] Z. Chyba, W. M. Grudzewski, Przedsiębiorczość akademicka w Polsce. Osiaganie przewagi konkurencyjnej w wyniku komercjalizacji technologii. Warsaw [in English].

2. Bąkowski, A. \& Głodek, P. \& Gołębiowski, M. \& Gulda, K. \& Jewtuchowicz, A. \& Klepka, M. \& Lityński, K. \& Matusiak, K. B. \& Matusiak, M. \& Mażewska, M. \& Niedzielski, P. \& Nowakowska, A. \& Stawasz, E. \& Zasiadły, K. (red) (2005). Innowacje i transfer technologii. Słownik Pojęć. Warsaw [in Polish].

3. Chyba, Z. \& Grudzewski, W. M. (2011). Przedsiębiorczość akademicka w Polsce. Osiaganie przewagi konkurencyjnej w wyniku komercjalizacji technologii. Warsaw [in Polish].

4. Grudzewski, W. M. \& Hejduk, I. K. (2001). Projektowanie systemów zarządzania. Warsaw [in Polish].

34. L. Kwieciński, Kształtowanie się polityki pro-innowacyjnej, Perspektywa europejska, narodowa i regionalna, Wrocław 2012, page 15. (typescript). 
5. Guliński, J. \& Zasiadły, K. (2005). Innowacyjna przedsiębiorczość naukowa światowe doświadczenia. Warsaw [in Polish].

6. Ministerstwo Nauki i Szkolnictwa Wyższego. Retrieved from http://www. nauka.gov.pl/ministerstwo/aktualnosci/aktualnosci/artykul/nowe-prawo-oszkolnictwie-wyzszym-podpisane-przez-prezydenta/ [in Polish].

7. Ministerstwo Nauki i Szkolnictwa Wyższego. Retrieved from http://www. nauka.gov.pl/szkolnictwo-wyzsze/dane-statystyczne-o-szkolnictwie-wyzszym [in Polish].

8. Jasiński, A. H. (2006). Innowacje i transfer techniki w procesie transformacji. Warsaw [in Polish].

9. Kwieciński, L. (2012). Kształtowanie się polityki pro-innowacyjnej Perspektywa europejska, narodowa i regionalna. Wrocław [in Polish].

10. Małecki, J. (2012). Transfer technologii. Warsaw [in Polish].

11. Marchesnay, M. (1993). Technology and Competitiveness, Small and Medium-sized Enterprises. Paris [in English].

12. Matusiak, K. B. (1995). Parki technologiczne. Instytucjonalne wspieranie przedsiębiorczości, procesów innowacyjnych i rozwoju regionalnego. Łódź [in Polish].

13. (2010). Przewodnik. Komercjalizacja B+R dla praktyków. Warsaw [in Polish].

14. Radosevic, S. (1999). International Technology Transfer and Catch-up in Economic Development. London [in English].

15. Sahal, D. (1982). Chance and Opportunity in Technological Innovation. Oxford [in English].

16. The Act of 26.06.1997 on Higher Vocational Schools, Dz. U. (Polish Journal of Laws) No. 96, pos. 590, with later change [in Polish].

17. The Act of 27.07.2005, Higher Education Law, Dz. U. (Polish Journal of Laws) from 2005, No 164, pos. 1365 [in Polish].

18. The Act of 31.03.1965 on Higher Military Education, Dz. U. (Polish Journal of Laws) from 1992, No. 10, pos. 40, with later change [in Polish].

19. It was defined in the Act of 8.08.1996 on procedures for the exercise of implementing powers conferred on the Treasury, Dz. U. (Polish Journal of Laws) no. 106, pos. 493 [in Polish].

20. The Act of 12.09.1990 on Higher Education, Dz. U. (Polish Journal of Laws) from 1990, No. 65, pos. 385 [in Polish].

Автор цієї статті приділяє особливу увагу новим викликам, які чекають на окремі наукові центри, що створюють таку специфічну додану вартість, як наукові дослідження та допомагають у їхній комерціалізації. Результатом такого роду наміченої співпраці вишів та підприємств є нова якість наукових досліджень стосовно конкретної користі для підприємства. У статті представлено процес перенесення технологій у практику та акцентовано увагу на інституційній системі, що дозволяє це робити.

Гіпотеза, викладена у цій статті, свідчить про те, що передача технологій, безумовно, потрібна для універ-

ситетів, однак поки що немає відповідного закону чи організаційних умов. Понад те, існує постійне суперництво та взаємне небажання допомоги між університетами та підприємцями. 


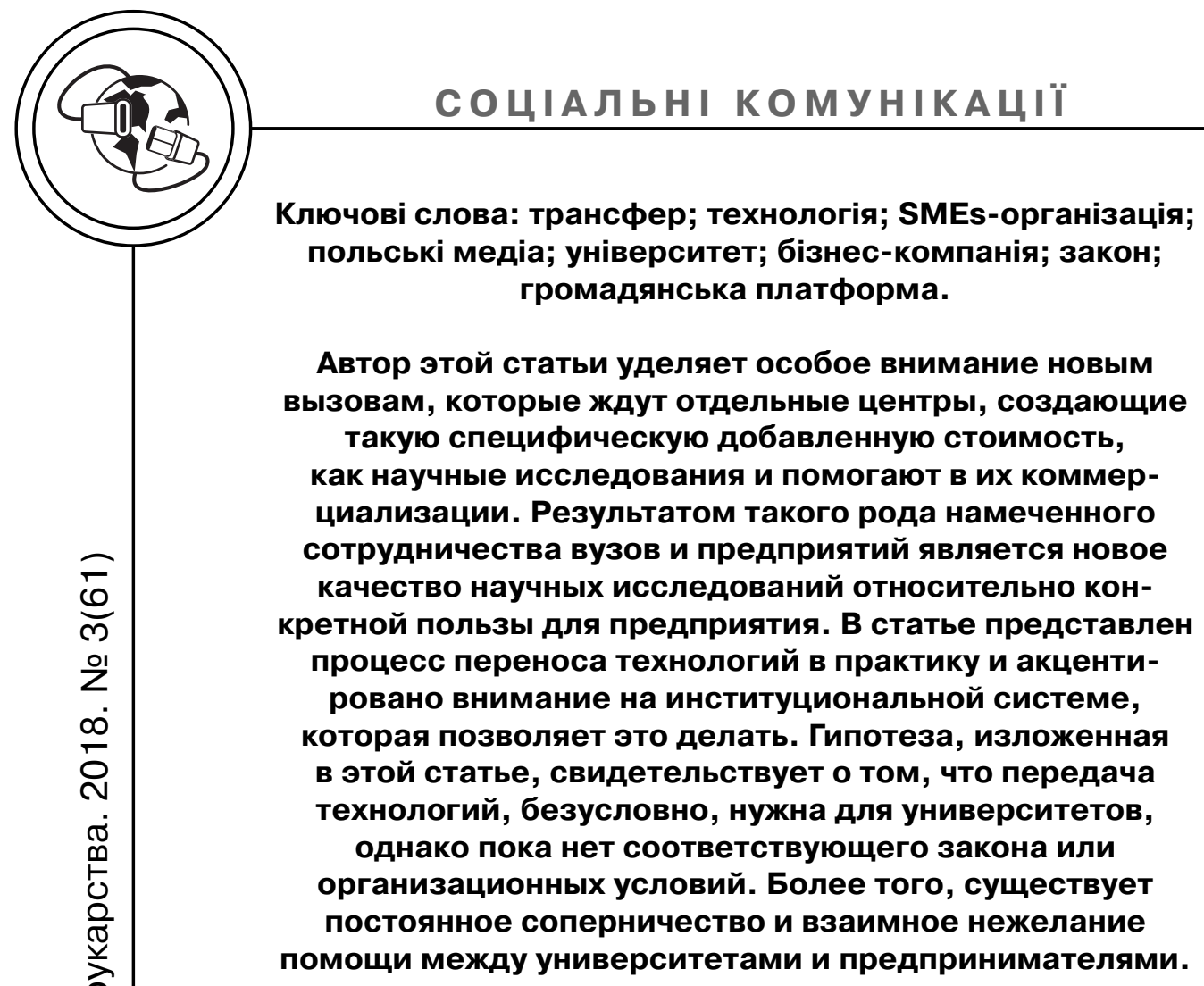

Ключевые слова: трансфер; технология; SMEs-организация; польские медиа; университет; бизнес-компания; закон; гражданская платформа. 